See discussions, stats, and author profiles for this publication at: https://www.researchgate.net/publication/319488015

\title{
Fracture Resistance of Flash Welded and Laser Welded Butt Joints in a Microalloyed HSLA Steel
}

Article in Key Engineering Materials · September 2017

DOI: 10.4028/www.scientific.net/KEM.754.248

CITATIONS

5 authors, including:

C. C. A. R. P. Baptista

University of São Paulo

70 PUBLICATIONS 416 CITATIONS

SEE PROFILE

S Torres

São Paulo State University

13 PUBLICATIONS 350 CITATIONS

SEE PROFILE
READS

27

Milton Sergio Fernandes de Lima

Universidade Federal de Ouro Preto

139 PUBLICATIONS 701 CITATIONS

SEE PROFILE

Some of the authors of this publication are also working on these related projects:

Estudo da Propagação de Trincas por Fadiga em Carregamentos de Amplitude Constante: UM NOVO MODELO CINÉTICO View project

Surface Engineering View project 


\title{
Fracture resistance of flash welded and laser welded butt joints in a micro-alloyed HSLA steel
}

\author{
Baptista C.A.R.P. ${ }^{1}$, Ribeiro H.V. ${ }^{1}$, Lima M.S.F. ${ }^{2}$, Torres M.A.S. ${ }^{3}$, Costa D.H.S. ${ }^{4}$ \\ ${ }^{1}$ EEL/USP - Engineering School of Lorena, University of São Paulo, Department of \\ Materials Engineering, Polo Urbo-Industrial, Gleba AI-6, zip code 12602-810 \\ Lorena/SP, Brazil. \\ ${ }^{2} I E A v / D C T A$ - Institute for Advanced Studies, São José dos Campos/SP, Brazil; \\ ${ }^{3}$ FEG/UNESP - College of Engineering, Campus Guaratinguetá, Department of \\ Mechanics, Guaratinguetá/SP, Brazil; \\ ${ }^{4}$ IAE/DCTA - Institute of Aeronautics and Space, Laboratório de Ensaios Estruturais, \\ Divisão de Sistemas Aeronáuticos (ASA), São José dos Campos/SP, Brazil; \\ email: carlos.baptista@usp.br
}

\begin{abstract}
High-strength, low-alloy (HSLA) steels are widely used in the automotive and oil industries due to their good mechanical properties and weldability. The selection of the welding process for components manufacturing depends on several factors, including the quality of the weld bead and the production capacity. The weld bead properties are affected by the welding process and by its parameters. The knowledge of the mechanical performance of the welded joint is essential to ensure structural reliability. In the present work, butt joints were produced from $6 \mathrm{~mm}$ thick plates of a microalloyed HSLA steel by flash welding and by laser welding processes, the latter using two different heat input conditions. The appearance, microsctructure and hardness profile of the weld beads were evaluated. The mechanical behavior of the welded joints was assessed by means of fracture toughness CTOD tests. The results, together with the fracture analyses of the tested specimens, allowed comparing the standards and predicates of these processes in the production of welded joints of microalloyed HSLA steel plates.
\end{abstract}

